\title{
THE EFFECTS OF ADRENOCORTICOTROPIC HORMONE AND CORTISONE IN THE ADRENOGENITAL SYNDROME ASSOCIATED WITH CONGENITAL ADRENAL HYPERPLASIA: AN ATTEMPT TO EXPLAIN AND CORRECT ITS DISORDERED HORMONAL PATTERN ${ }^{1,2}$
}

\author{
By FREDERIC C. BARTTER, 3 FULLER ALBRIGHT, ANNE P. FORBES, ALEX- \\ ANDER LEAF, 4 ELEANOR DEMPSEY, AND EVELYN CARROLL
}

\author{
(From the Department of Medicine of the Harvard Medical School and the Medical Service \\ of the Massachusetts General Hospital, Boston)
}

(Submitted for publication November 2, 1950; accepted, December 9, 1950)

The adrenogenital syndrome associated with congenital adrenal hyperplasia (1) is in many of its aspects the direct opposite of the other syndrome which may result from adrenal hyperplasia, namely, Cushing's syndrome (2). For example, the former is characterized by rapid growth before epiphyseal closure, and an increase in strength, muscle mass, and skin thickness, whereas the latter is characterized by cessation of growth before epiphyseal closure, and a decrease in strength, muscle mass and skin thickness.

Since the effect of adrenocorticotropic hormone (ACTH) in subjects with normal adrenals is essentially to produce a temporary "Cushing's syndrome medicamentosa" (3-7) it was of interest to observe the effects of ACTH in the adrenogenital syndrome. The first part of this report concerns the effects of ACTH in three female patients with the adrenogenital syndrome.

The results, which were surprising, led to the supposition that cortisone might inhibit the excessive production of androgens in these patients. The second part of this report concerns the effects of cortisone in two female patients with the adrenogenital syndrome.

\section{METHOD}

With the exception of the long-term studies which are still in progress (vide infra) all studies were carried out

1 Reported in part at the Proceedings of American Society for Clinical Investigation, May 1, 1950. (J. Clin. Invest., 1950, 29, 797.)

2 The expense of these studies was defrayed by a grant from the Rockefeller Foundation, a grant from Ayerst, McKenna and Harrison, Ltd., and grants from the American Cancer Society. A bed supported by Mr. Edward Mallinckrodt, Jr., on the Metabolic Ward was used for these studies.

8 Surgeon, U.S.P.H.S., National Heart Institute.

4 National Research Council Fellow in the Medical Sciences, 1949-1951. on the Metabolic Ward. The diet and fluid intake were kept constant throughout each study. Stools were collected in six day periods, and urines in one to six day pools. Stools and diets were analyzed for $\mathrm{N}, \mathrm{P}, \mathrm{Ca}, \mathrm{K}$, $\mathrm{Na}$, and $\mathrm{Mg},{ }^{5}$ and urines for these constituents and for $\mathrm{Cl}$, "reducing steroids," and 17-ketosteroids. Fasting blood for determination of circulating eosinophils, and of serum glucose, $\mathrm{Ca}, \mathrm{P}, \mathrm{Mg}^{5} \mathrm{Na}, \mathrm{K}, \mathrm{Cl}$, and $\mathrm{CO}_{2}$ was drawn at appropriate intervals. The following methods were used: Magnesium-Briggs (8) ; reducing steroidsTalbot and his associates (9) and Heard, Sobel and Venning (10) ; eosinophil counts- Hills, Forsham and Finch (11), except that the blood was diluted 1:10 instead of $1: 20$; the remaining determinations-as described elsewhere (12).

\section{CASE HISTORIES}

C. O., M.G.H. No. 169,536 , was a 13 year old girl who had been seen first at the age of five because of the presence of pubic hair since the age of two. Growth proceeded rapidly, with markedly advanced bone age, and ceased by the age of nine with epiphyseal closure. Menses had not appeared.

Physical examination revealed an abnormally muscular girl, a height and span both of $571 / 2$ inches, a large thyroid cartilage, a deep voice, temporal recession of the hairline, hirsutism of face and body, a large amount of pubic and axillary hair, scant breast tissue, a very large clitoris, absent labia minora, and a common external orifice of urethra and vagina. $\mathrm{X}$-rays revealed no adrenal tumor after air insufflation, and a normal skull. Repeated chemical analyses revealed normal serum glucose, $\mathrm{Na}, \mathrm{Cl}, \mathrm{K}, \mathrm{Ca}, \mathrm{P}, \mathrm{CO}$, content, and alkaline phosphatase. A Cutler-Power-Wilder test revealed a normal four hour chloride excretion. Twenty-four hour urine specimens contained normal amounts of reducing steroids, subnormal amounts (less than 2.8 mouse units) of "cortin" (13), and very large amounts (60 to $70 \mathrm{mg}$.) of $17-$ ketosteroids.

An electroencephalogram was read by Dr. John Abbott as follows: "This is an abnormal record for her age. It shows a mild, diffuse, slow-wave cerebral dysrhythmia (many six per second waves). Voltages are slightly higher on the right."

T. McH., M.G.H. No. 586, 528, was a ten year old girl

5 Not done on patient C. O. 


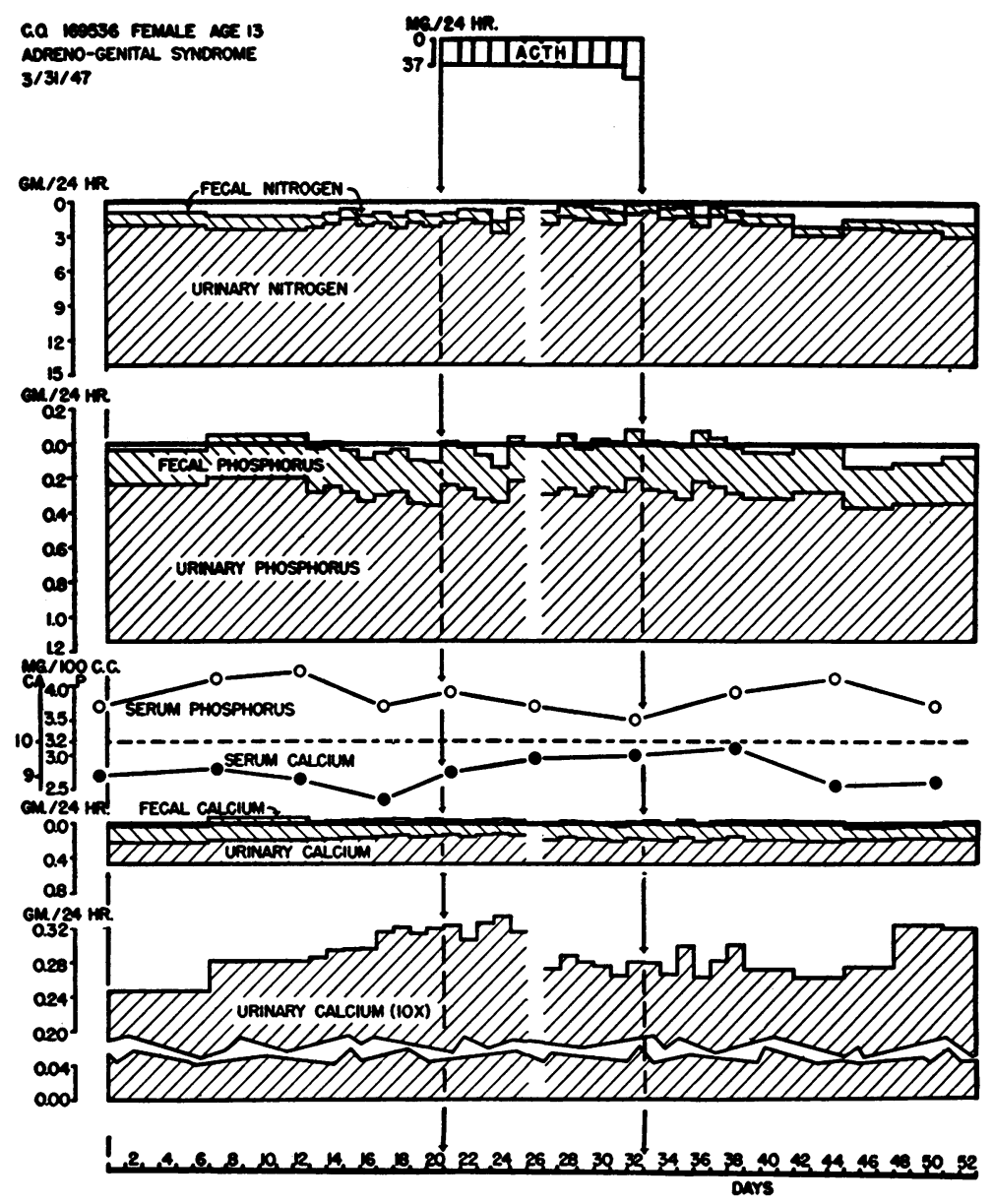

Fig. 1. N, P, and Ca Balances, Urinary Ca, and Serum P and Ca during Administration of ACTH to C. O., a 13 Year Old Female with the Adrenogenital Syndrome

Balance data in this and subsequent charts are plotted as follows: There is a horizontal base line; intake is charted downward from this base line; the urinary and fecal excretions are then measured upward from the intake line towards the base line. If the output (fecal and urinary) exceeds the intake, the final level will be above the base line; if it does not, the final level will be below the base line. Thus a negative balance is indicated by a shaded area above the base line, and a positive balance by a clear area below the base line. The scales for $\mathrm{N}, \mathrm{P}, \mathrm{Ca}$, and $\mathrm{K}$ metabolism are so chosen that (for changes in protoplasm and bone) the area representing $P$ balance should equal the sum of the corresponding areas for $\mathrm{N}$ and $\mathrm{Ca}$; and that representing $\mathrm{K}$ balance should equal that for $\mathrm{N}$. 
who was referred to us by Dr. Gertrud Ryersbach. She had been seen first at the age of eight because of the presence of pubic hair since the age of four. Growth proceeded rapidly, with markedly advanced bone age. Menses had not appeared except upon withdrawal of estrin therapy, which had been tried without appreciable effect on the virilism.

Physical examination revealed a well-developed girl, a height and span of 65 and $653 / 4$ inches respectively, a slightly enlarged thyroid cartilage, a voice not deeper than that of a normal adult female, a large amount of pubic and a moderate amount of axillary hair, a moderate amount of breast tissue (estrogen therapy), a very large clitoris, and otherwise normal external genitalia. $\mathrm{X}$-rays revealed a normal skull. Repeated chemical analyses revealed normal serum glucose, $\mathrm{Na}, \mathrm{Cl}, \mathrm{K}, \mathrm{Ca}, \mathrm{P}, \mathrm{CO}$ c content, and alkaline phosphatase. A Kepler water test gave a normal result. Twenty-four hour urine specimens contained normal amounts of reducing steroids, and large amounts (14 to $18 \mathrm{mg}$.) of 17-ketosteroids.

Ten electroencephalograms were read by Dr. John Abbott as follows: "These are abnormal records for her age. They show severe diffuse, slow-wave cerebral dysrhythmia (random waves and paroxysmal runs, notably three per second waves reaching 150 micro-volts, and six per second waves reaching 175 micro-volts). Voltages are markedly higher, and dysrhythmia is more pronounced, on the right. These abnormalities are especially

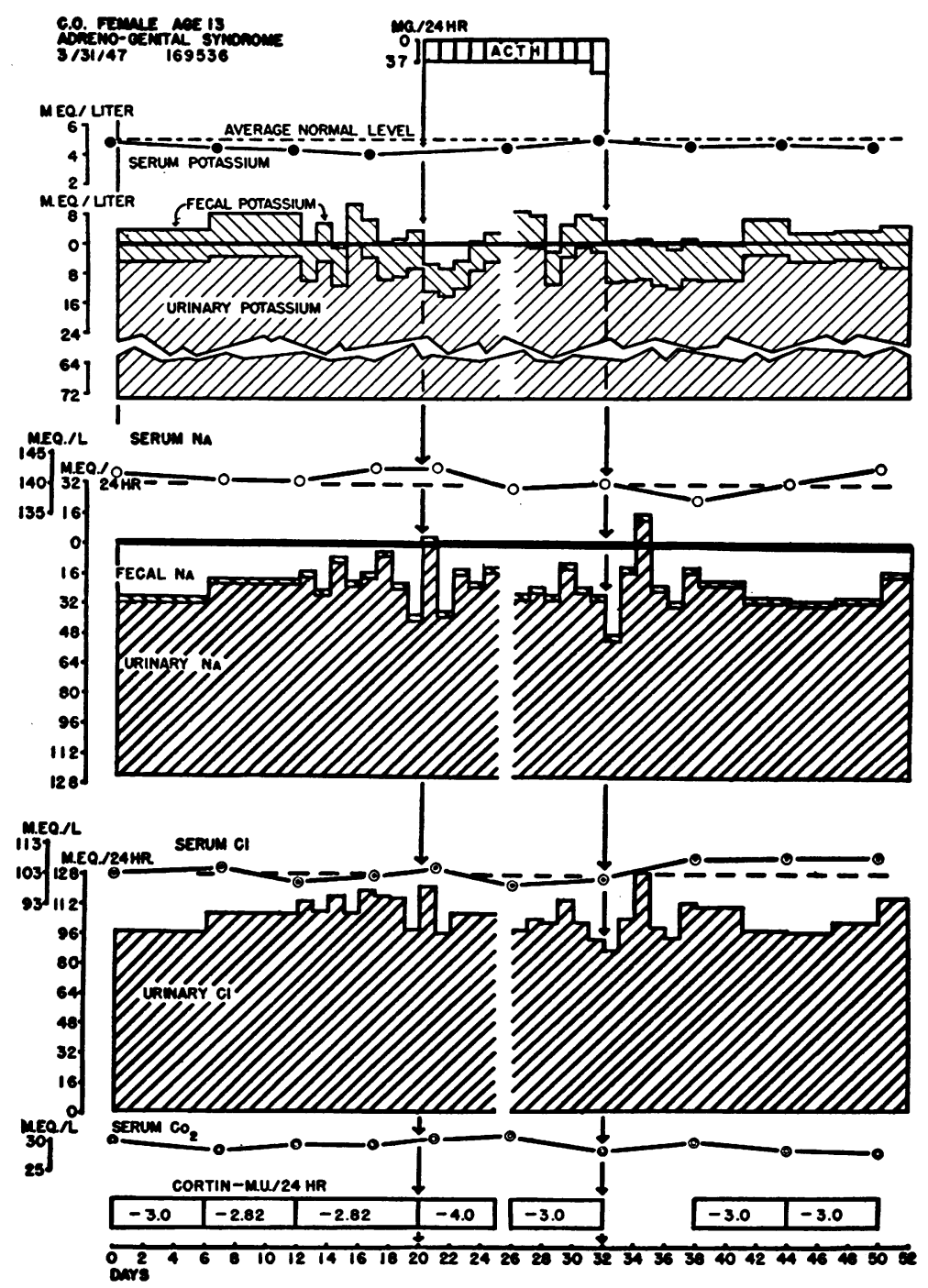

Fig. 2. K and Na Balances, Urinary Cl and Cortin, and Serum K, Na, Cl and CO, Content in Experiment Shown in Figure 1

For interpretation of cortin see Forbes, Griswold and Albright (25). 
marked in the occipitoparietal region a little to the right of the midline. There are traces of normal alpha activity at eight per second and 50 micro-volts."

On explorations by Doctor Oliver Cope, the internal genitalia were found to be of the normal female structure; ovarian biopsy revealed developing follicles; the right adrenal gland was not grossly abnormal to palpation; and the left adrenal cortex showed hypertrophy on biopsy.

R. H., M.G.H. No. 401, 611, was a 12 year old girl who had been seen first at the age of five because of the presence of an enlarged clitoris since the age of three months and pubic hair since the age of four. Growth proceeded rapidly, with advanced bone age, and ceased by the age of nine with epiphyseal closure. Menses had not appeared, even on withdrawal of estrogen therapy, which

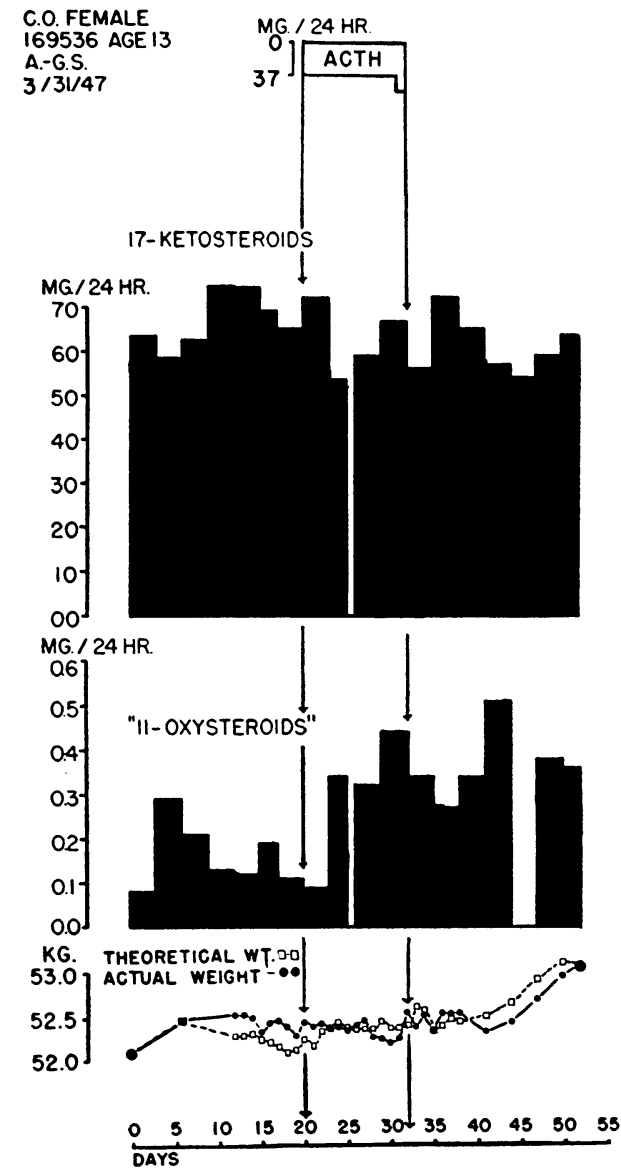

Fig. 3. 17-Ketosteroids AND "11-Oxycorticosteroids," Actual Weight, and Theoretical Weight Based on N, Na, and K DURing Experiment Shown IN Figure 1

For calculation of theoretical weight see Reifenstein and associates (12). The upper limit of normal for "11-oxycorticosteroids" by this method is $0.44 \mathrm{mg}$. per 24 hours (26). had been tried without appreciable effect on the virilism.

Physical examination revealed a well-developed girl, a height and span both of 62 inches, a slightly enlarged thyroid cartilage, a moderately deep voice, slight temporal recession of the hairline, hirsutism of the upper lip and body, large amounts of pubic and axillary hair, a moderate amount of breast tissue (estrogen therapy), a very large clitoris, absent labia minora, and a common external orifice of urethra and vagina. $\mathrm{X}$-rays revealed normally placed kidneys and a normal skull. Repeated chemical analyses revealed normal serum glucose, $\mathrm{Na}$, $\mathrm{Cl}, \mathrm{K}, \mathrm{Ca}, \mathrm{P}, \mathrm{CO}_{2}$ content, and alkaline phosphatase. Twenty-four hour urine specimens contained normal amounts of reducing steroids and large amounts (17 to $25 \mathrm{mg}$.) of 17 -ketosteroids.

Four electroencephalograms were read by Dr. John Abbott as follows: "These are abnormal records for her age. They show a diffuse, slow-wave, cerebral dysrhythmia (four to six per second waves). The abnormality is somewhat more marked on the left. There is some normal alpha activity at around eight to nine per second and 40 micro-volts."

\section{RESULTS}

The overall design of each metabolic study may be seen by inspection of Figures 1, 4, and 7 . Seven courses of therapy were given as shown in Table I. The metabolic effects of the two hormones are best considered separately.

\section{I. $A C T H$}

\section{a) Nitrogen metabolism}

ACTH did not produce a significantly negative nitrogen balance in any of the four courses of administration (Figures 1, 4, and 7). Indeed, when a daily dose of $200 \mathrm{mg}$. was given, there was actual nitrogen retention. This observation is contrary to the experience of ourselves $(14,15)$ and others (3-6) in patients with essentially normal adrenal cortical function. Figure 10 is a scatter diagram contrasting the total six day $\mathrm{N}$ excretion of other patients given comparable doses of $\mathrm{ACTH}$ with that of these patients.

\section{b) Phosphorus metabolism}

When $200 \mathrm{mg}$. of ACTH were given to patient $\mathrm{T}$. $\mathrm{McH}$. (Figure 4) there was retention of $\mathrm{P}$ commensurate with that of $\mathrm{N}$, on the assumption that protoplasm was formed (12). In the other experiments (Figures 1 and 7) ACTH did not affect $\mathrm{P}$ balance or serum $\mathrm{P}$. 
TABLE I

The dosage and duration of ACTH and cortisone administration and the composition of the diet in the metabolic studies reported

\begin{tabular}{|c|c|c|c|c|c|c|c|c|c|c|}
\hline $\begin{array}{c}\text { Wt. at } \\
\text { start of } \\
\text { treatment }\end{array}$ & Patient & Drug & \multicolumn{2}{|c|}{ Daily dose } & $\underset{\substack{\text { Units } \\
\text { pressor } \\
\text { per day }}}{ }$ & $\begin{array}{l}\text { No. of } \\
\text { days }\end{array}$ & CHO & Fat & Protein & Calories \\
\hline $\begin{array}{l}\mathrm{kg} . \\
52\end{array}$ & C. 0. & ACTH & $\begin{array}{c}m g . * \\
37\end{array}$ & $\begin{array}{c}\text { mg.* per kg. } \\
.71\end{array}$ & 2.6 & $12 \ddagger$ & 250 & 103 & 83 & 2258 \\
\hline 55 & T. McH. & ACTH\& & 84 & 1.53 & 4 & 12 & 246 & 61 & 74 & 1828 \\
\hline 60 & T. McH. & ACTH & 200 & 3.33 & 8 & 12 & 388 & 57 & 59 & 2317 \\
\hline 47 & R. H. & ACTH & 84 & 1.79 & 4 & 9 & 179 & 57 & 54 & 1446 \\
\hline 53 & T. McH. & $\begin{array}{l}\text { Cortisone } \\
\text { acetate } \delta\end{array}$ & 100 & 1.90 & & 12 & 246 & 61 & 74 & 1828 \\
\hline 45 & R. H. & $\begin{array}{l}\text { Cortisone } \\
\text { acetate }\end{array}$ & 100 & 2.22 & & 12 & 179 & 57 & 54 & 1446 \\
\hline 43 & R. H. & $\begin{array}{l}\text { Combined ACTH } \\
\text { and cortisone }\end{array}$ & $\begin{array}{r}88 \\
100\end{array}$ & $\begin{array}{l}2.05 \\
2.32\end{array}$ & 4 & 8 & 179 & 57 & 54 & 1446 \\
\hline
\end{tabular}

* Expressed as equivalents of Armour Standard La 1A.

t The pressor is present in the ACTH as contaminant and was assayed by the Armour Laboratories.

$\ddagger$ On the 12 th day, $55 \mathrm{mg}$., or $1.06 \mathrm{mg}$. per kg., were given.

$\$$ Stilbestrol, $5 \mathrm{mg}$. a day, was administered throughout this experiment.
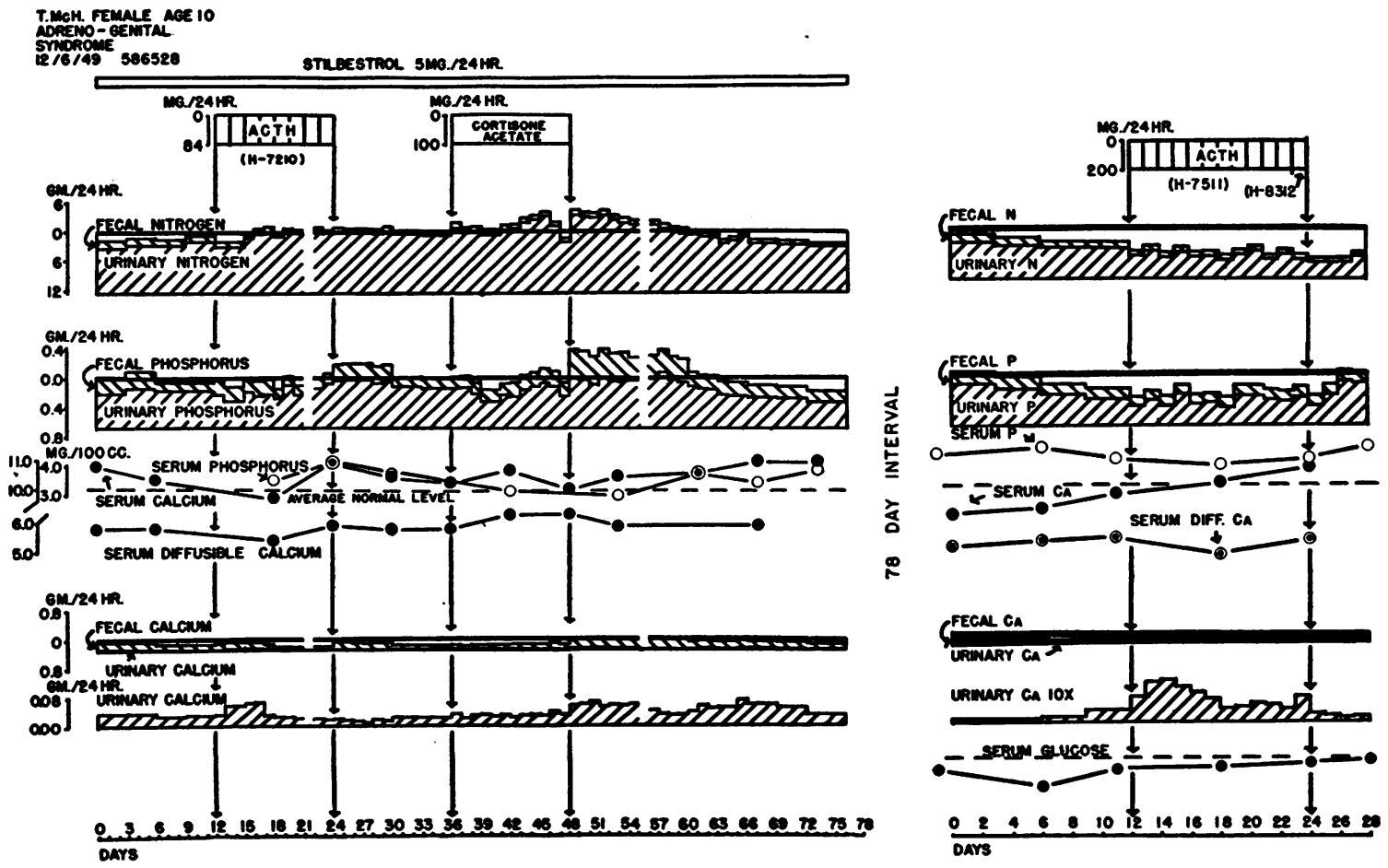

Fig. 4. N, P, and Ca Balances, Urinary Ca, Serum P, Ca and Diffusible Ca during Administration of aCth and Cortisone to T. McH., a Ten Year Old Female with the Adrenogenital Syndrome

The determinations of diffusible $\mathrm{Ca}$ in this and the subsequent experiments were done for us by Dr. John Dawson. 


\section{c) Calcium metabolism}

There was a rise in urinary calcium with ACTH in all experiments save that on C.O. (Figure 1). As discussed elsewhere $(7,16)$ this effect may be due to the pitressin present in the ACTH as a contaminant (Table I). Comparison of the actual weight curves with the "theoretical" weight curves based on N-plus-K-plus $\mathrm{Na}$ (Figures 3, 6, and 9) shows that water was retained without electrolytes during ACTH therapy-presumably a pitressin effect-in the experiments on $\mathrm{T}$. $\mathrm{McH}$. and R. H. Water was not retained in C. O., and she showed no rise in urinary calcium.

\section{d) Potassium metabolism}

ACTH produced a slight, unsustained retention of $\mathrm{K}$ in all experiments. This is in contrast to our previous experience $(7)$, wherein a transi- tory rise of urinary $\mathrm{K}$, with negative balance, on the first day of therapy, and a transitory fall, with positive balance, on the first or second day after stopping have been among the most constant effects of ACTH. This is shown in Figure 11, wherein the effect of ACTH on urinary $\mathrm{K}$ excretion in 12 experiments on patients with essentially normal adrenal cortical function is contrasted with that in these patients.

\section{e) Sodium and chloride metabolism}

In the first experiment on $\mathrm{T} . \mathrm{McH}$. and that on C. O., ACTH had no appreciable effect on $\mathrm{Na}$ or $\mathrm{Cl}$ metabolism (Figures 2 and 5). In the other two experiments, slight loss of $\mathrm{Na}$ and $\mathrm{Cl}$ occurred (Figures 5 and 8). As discussed elsewhere, the effect of these preparations of ACTH upon $\mathrm{Na}$ and $\mathrm{Cl}$ appears to be a resultant of the
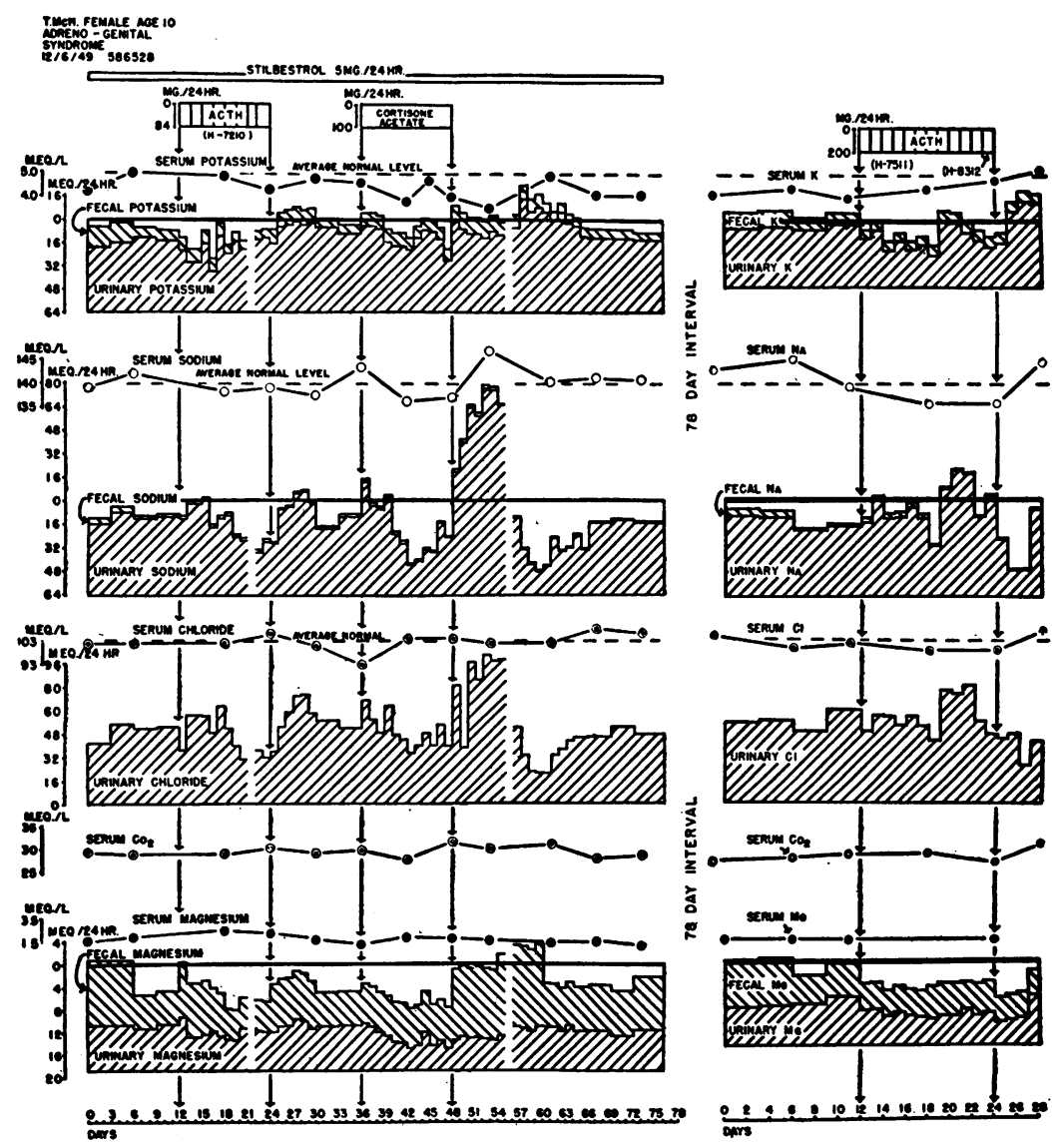

Fig. 5. K, Na and Mg Balances, Urinary $C_{l}$ and Serum $\mathrm{K}, \mathrm{Na}, \mathrm{Cl}, \mathrm{CO}$ Content, and Mg during the Experiment Shown in Figure 4 

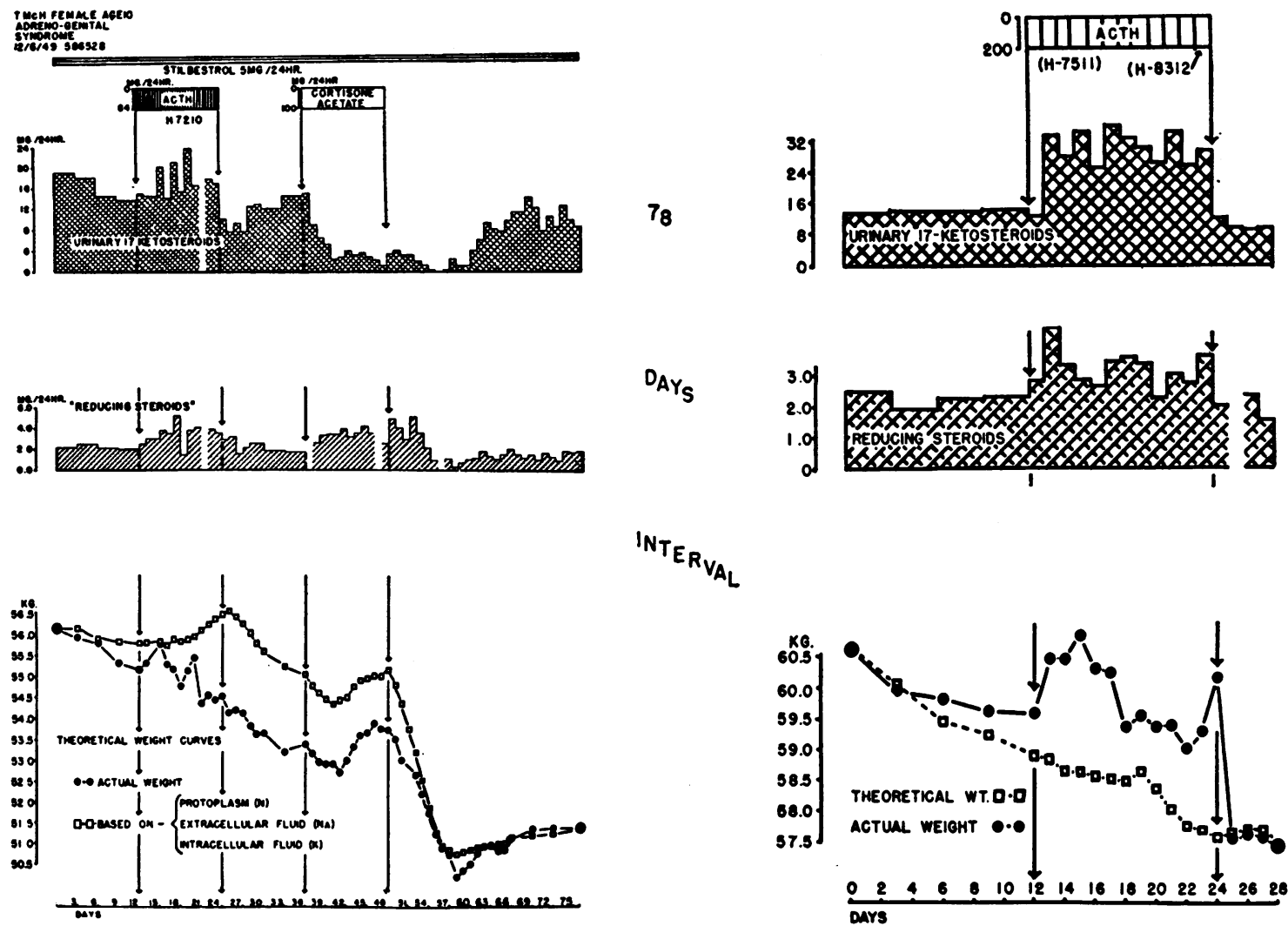

Fig. 6. Urinary 17-Ketosteroids and "Reducing Steroids," Actual and Theoretical Weight Based on N, Na, and $\mathrm{K}$ during Experiment Shown in Figure 4

The upper limit of normal for reducing steroids by this method is $5 \mathrm{mg}$. per 24 hours.

sodium-retaining properties of the adrenal steroids and the sodium diuretic properties of contaminating posterior pituitary substances $(7,17)$. Similar doses of these preparations of ACTH produce sodium retention in patients with essentially normal adrenal cortical function, in spite of the presence of pitressin in quantities equal to or greater than those given here. Thus there is no evidence in these patients that sodium-retaining steroids were released in response to ACTH.

Lewis and Wilkins (18) reported sodium loss following administration of ACTH for a single day to two patients with the adrenogenital syndrome. The amount of contaminating pitressin their patients received was relatively high. It should be noted, however, that sodium retention very frequently fails to occur during the first 24 hours of ACTH therapy to patients who later show marked retention (4-7).

\section{f) Magnesium metabolism}

$\mathrm{Mg}$ balances were measured during three of the four studies with ACTH. When a daily dose of $200 \mathrm{mg}$. was given (Figure 5) urinary $\mathrm{Mg}$ fell. In the other experiments (Figures 5 and 8 ) no consistent effect on $\mathrm{Mg}$ metabolism was noted.

\section{g) 17-Ketosteroids}

In all subjects the 17-ketosteroid excretion was very high (19) for the age of the patient. In patient C. O., ACTH produced no further rise in 17-ketosteroid excretion (Figure 3) ; in T. $\mathrm{McH}$., a questionable rise was produced with a dosage of $84 \mathrm{mg}$., and a marked rise with $200 \mathrm{mg}$. a day (Figure 6). In patient R. H. a marked rise was produced with $84 \mathrm{mg}$. a day (Figure 9).

\section{h) Reducing steroids ("11 oxysteroids")}

ACTH did not produce a significant rise in reducing steroids in any of the experiments (Figures 


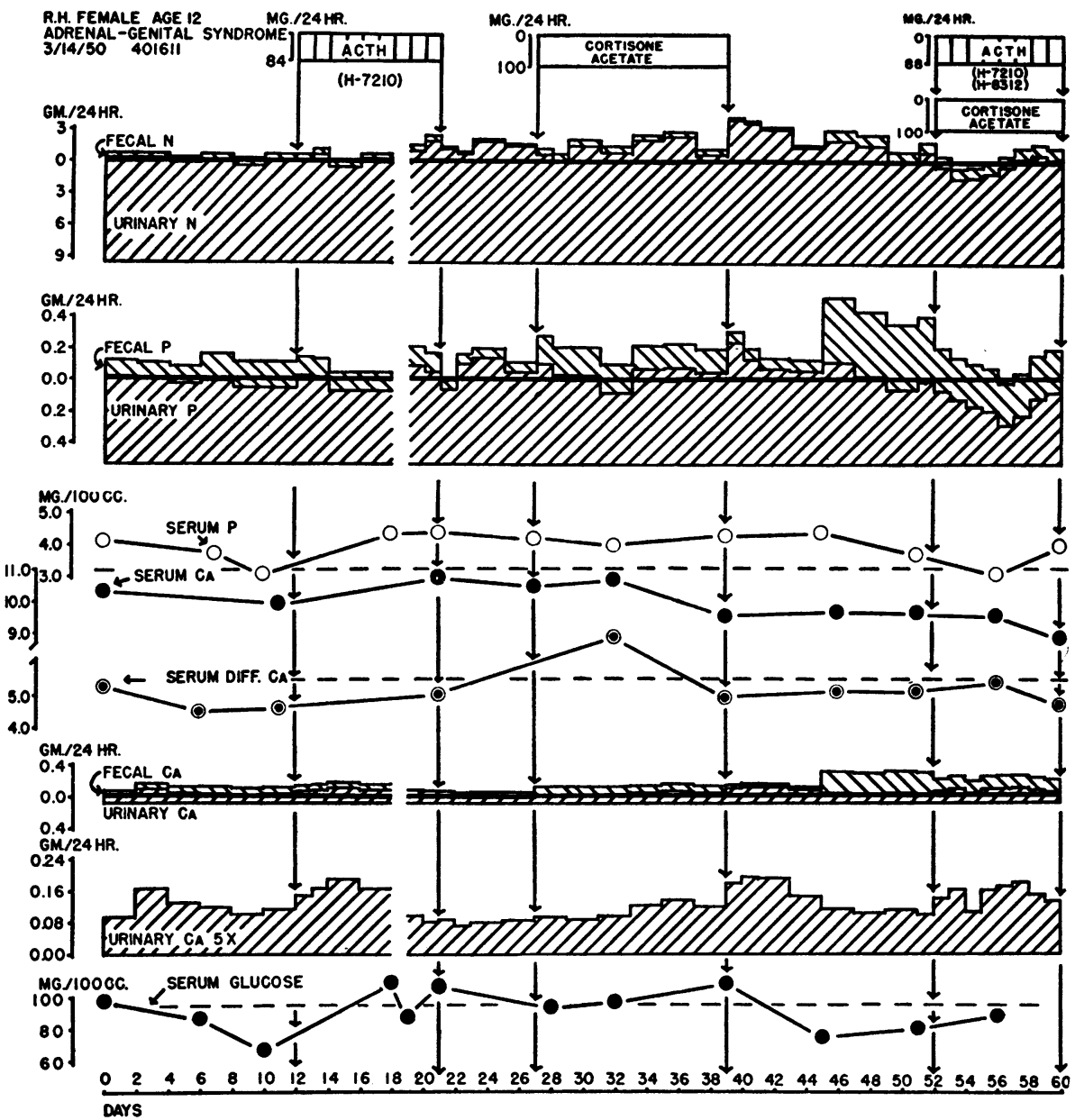

Fig. 7. N, P, and Ca Balances, Urinary $C_{a}$ and Serum $P, C_{A}$, and Diffusible $C_{a}$ and Glucose During Administration of ACTH and Cortisone to R. H., a 12 Year Old Female with the Adrenogenital Syndrome

3,6 , and 9). This result is in striking contrast to the elevations of urinary reducing steroids of two to ten times the normal values which have been consistently reported following similar doses of ACTH $(3,4,6,15)$.

\section{i) Circulating eosinophils}

The initial counts of fasting eosinophils were high in the two patients ( $\mathrm{T} . \mathrm{McH}$. and R. H.) in whom they were done. With ACTH (Figure 12) there was a transient fall, followed by a rise to or above the initial values, despite continued ACTH therapy. This observation is in contrast to the well-documented observation (3-6) that the circulating eosinophils fall to approximately zero and remain there with comparable doses of ACTH in patients with essentially normal adreno-cortical function.

\section{j) Glycosuria}

No patient developed glycosuria at any time during therapy.

\section{Summary of results of $A C T H$ therapy}

In many respects, these patients responded abnormally to ACTH. The failure to increase significantly the excretion of reducing steroids, to develop a negative $\mathrm{N}$ balance, or to show a large and sustained fall of circulating eosinophils is an indication that the output of "carbohydrate-active" 
steroids" ("sugar" hormone) following ACTH is markedly subnormal. The failure to develop transient $\mathrm{K}$ diuresis is an indication that the output of either "carbohydrate-active" or "salt-retaining" steroids or both is subnormal-if, indeed, these are separate hormones (20). The failure to develop $\mathrm{Na}$ and $\mathrm{Cl}$ retention is an indication that the output of "salt-retaining" steroids is similarly impaired.

In one respect these patients responded normally to ACTH. In spite of high initial levels, the urinary 17-ketosteroid excretion rose in all experiments except one, that on $\mathrm{C}$. O. In this experiment the initial level was highest, and the lowest dose of ACTH was given. The urinary 17-

6 Probably these consist of Compound F, Compound E, or closely related steroids. ketosteroids are presumably (2) an index of the adrenal androgen which is responsible for the virilism in these patients, and the initially high values are of course a cardinal feature of the disease.

These findings suggested two metabolic disorders in the pathogenesis of this condition: diminished ability of the adrenal cortex to respond to ACTH with an increased output of carbohydrate-active and salt-retaining steroids, and an increased production of ACTH (vide infra) resulting in the abnormally high production of adrenal androgen (see also Figure 13).

It was then postulated that a carbohydrateactive adrenal cortical hormone such as cortisone should depress the production of ACTH and thus diminish adrenal androgen production. Conse-

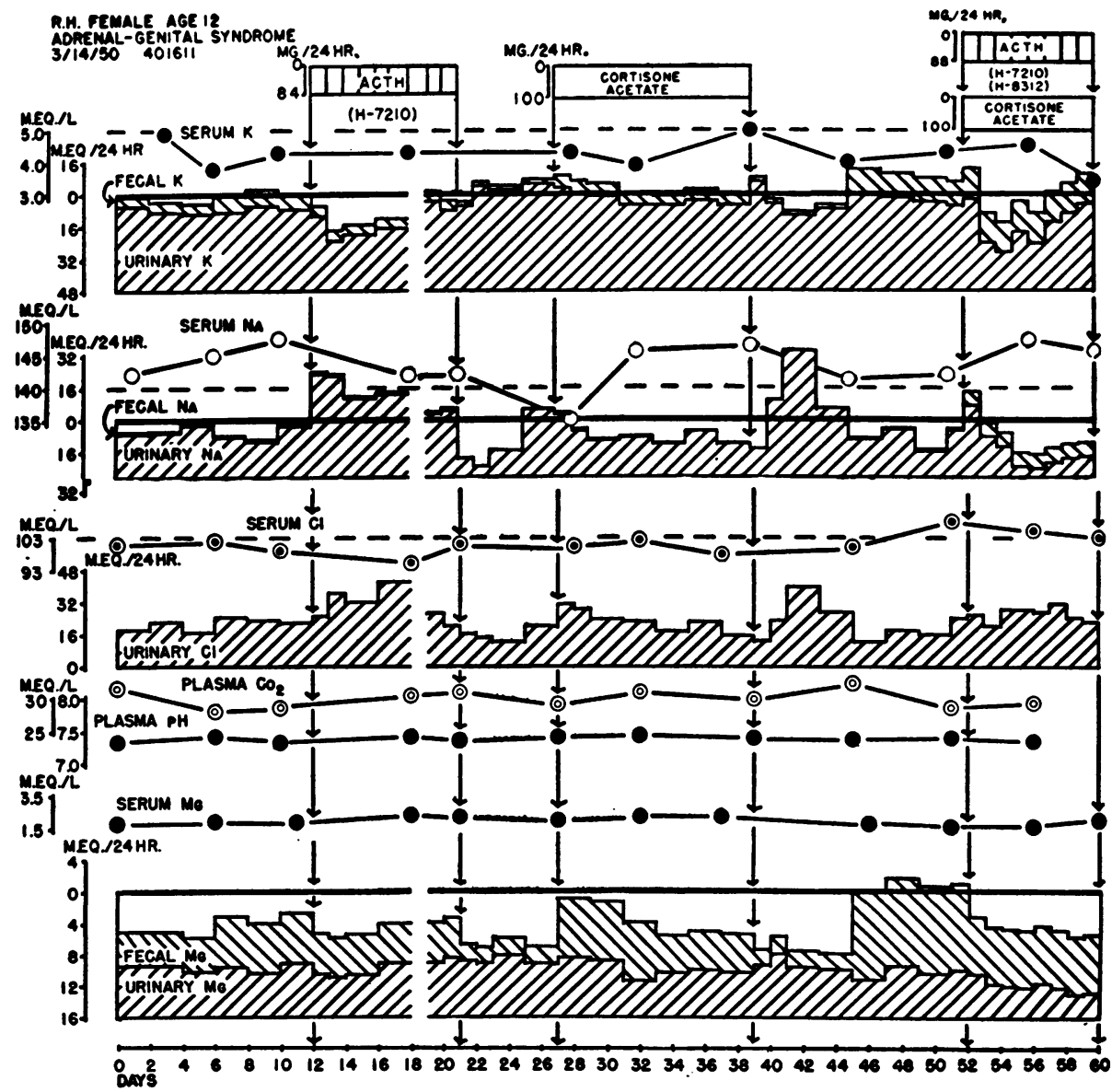

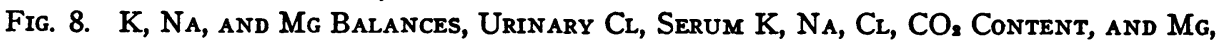
and Plasma pH during the Experiment Shown in Figure 7 
quently, cortisone acetate was administered in doses of $100 \mathrm{mg}$. a day for 12 days to patients T. $\mathrm{McH}$. and R. H.

\section{Cortisone}

The metabolic effects of cortisone are shown in Figures 4-9. The changes in $\mathrm{P}, \mathrm{Ca}, \mathrm{K}, \mathrm{Na}$, and $\mathrm{Cl}$ metabolism and in excretion of reducing steroids are not remarkable, and do not differ essentially from those previously reported (6) following the use of cortisone acetate at similar dosages. There was a slight fall of urinary $\mathrm{Mg}$ in both patients.

Cortisone produced a rise in urinary $\mathrm{N}$ in both patients, resulting in a markedly negative $\mathrm{N}$ balance in $\mathrm{T} . \mathrm{McH}$. (Figure 4) and increasing the already existing negative $\mathrm{N}$ balance in $\mathrm{R}$. $\mathrm{H}$. (Figure 7). This result is contrary to those of Sprague and associates (6), Clark, Ropes and Bauer (21), and ourselves (22), following the use of cortisone at this dosage in patients with other syndromes. Sprague and his co-workers state, "As a rule, the augmentation of nitrogen excretion was slight or absent when the dose of cortisone was $100 \mathrm{mg}$. daily."

The second striking result of cortisone therapy was the marked progressive fall in 17-ketosteroid excretion in both patients (Figures 6 and 9). The urinary 17-ketosteroids remained low for eight (R. H.) and 12 (T. McH.) days, then rose gradually to the pre-injection levels. A similar depression of 17-ketosteroids with cortisone in a patient with the adrenogenital syndrome has been reported by Wilkins and his colleagues (23).

\section{ACTH and Cortisone}

As stated above, we had believed, a priori, that the effect of cortisone would be to lower the uri-

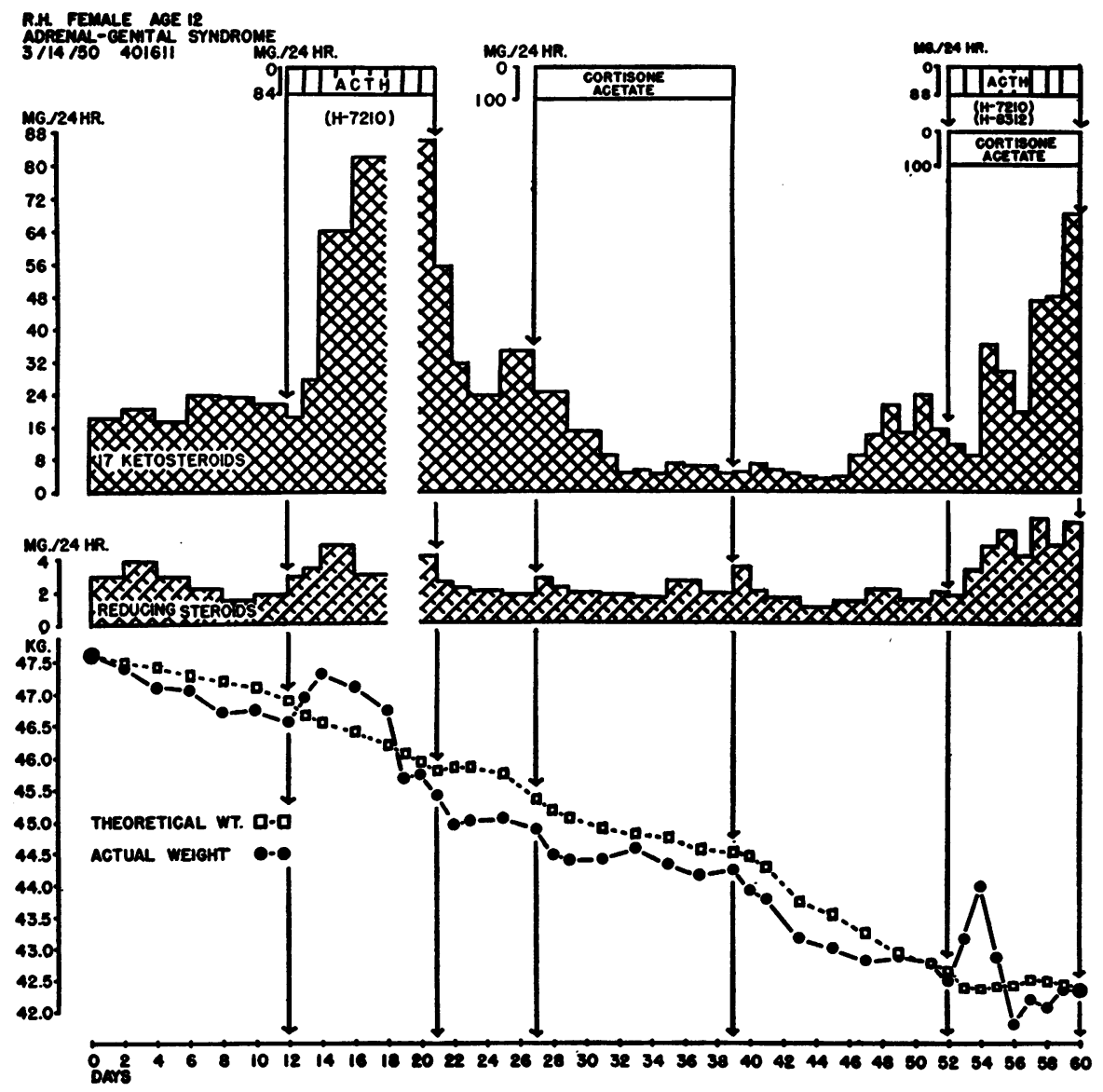

Fig. 9. Urinary 17-Ketosteroids, "Reducing Steroms," Actual Weight, and Theoretical Weight Based on N, Na, and K during Experiment Shown in Figure 7 


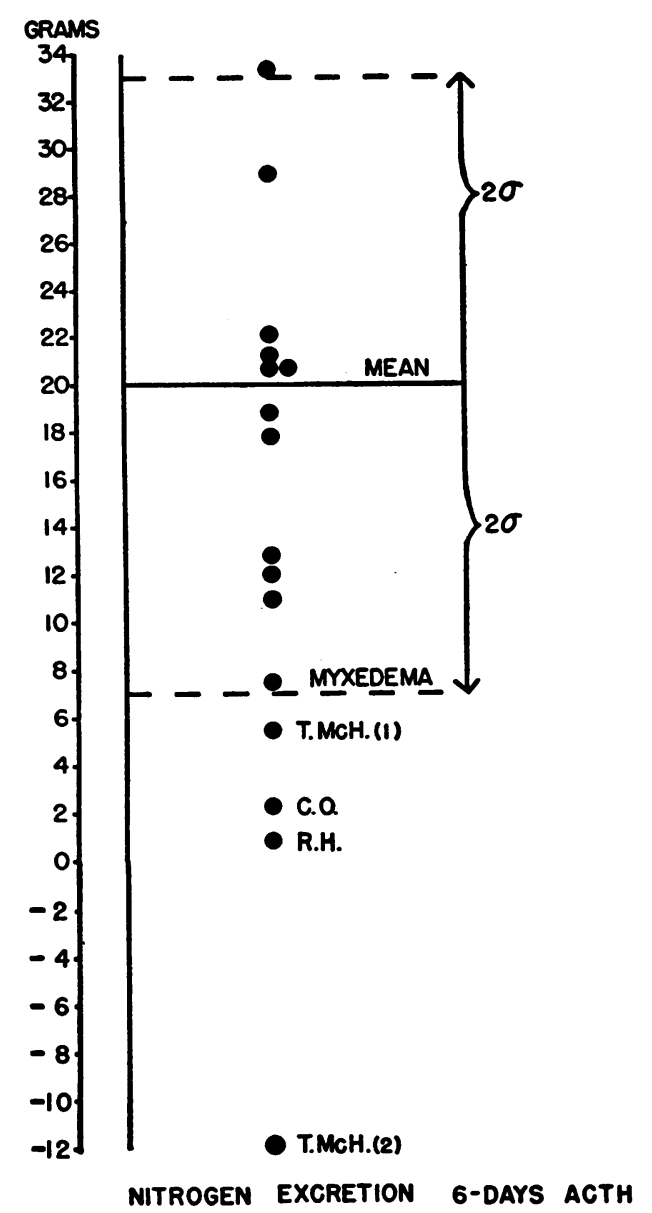

Fig. 10. The Total $N$ Excretion during the First Six Days of ACTH Administration to the Three Patients Reported, Contrasted with that in 11 Comparable Experiments on Patients with Essentially Normal Adrenal Cortical Function, and One on a Patient with Myxedema

Nitrogen excretions were calculated as deviations from the average of control values. Note decreased $\mathrm{N}$ excretion in patients with the adrenogenital syndrome, and actual $\mathrm{N}$ retention with $200 \mathrm{mg}$. of $\mathrm{ACTH}$ in $\mathrm{T}$. $\mathrm{McH}$. (2).

nary 17-ketosteroid excretion by depressing pituitary ACTH production, and not by direct action on the adrenal gland. To provide further evidence on this point we decided to administer ACTH and cortisone together to patient $R$. $H$. If cortisone has a direct action on the adrenal cortex it should decrease the response to administered ACTH. The results show that the rise in 17-ketosteroid excretion resulting from ACTH together with cortisone (Figure 9, days 53 through 60 ) did not differ essentially from that resulting from ACTH alone (Figure 9, days 13 through 20). Thus they do not show direct action of cortisone on the adrenal cortex or on its response to ACTH in this patient. Hence, they support the view that cortisone acts by inhibiting endogenous ACTH.

\section{DISCUSSION}

\section{a) Nitrogen metabolism}

Consideration of the adrenogenital syndrome, which may be associated with either hyperplasia or tumor of the adrenal cortex, leaves little doubt that the adrenal cortex may produce steroids which have virilizing properties. There is considerable circumstantial evidence (2) that the measurement of urinary 17-ketosteroids provides an index of the quantities of such steroids being produced. Further, there is clinical evidence (2) that these steroids may have somatotropic, nitrogen-retaining, as well as virilizing properties.

The present study provides two pieces of indirect evidence in support of the latter point. In the first place, when T. $\mathrm{McH}$. received $200 \mathrm{mg}$. of $\mathrm{ACTH}$ a day, there was a marked rise in 17ketosteroid excretion without a significant rise in urinary reducing steroids. Under these circumstances, nitrogen retention was increased. ${ }^{7} \mathrm{Ni}$ trogen retention with $\mathrm{ACTH}$ has not heretofore been described, presumably because nitrogen loss with "sugar" hormone outweighs any nitrogen retention due to somatotropic hormones. In the second place, when $\mathrm{T} . \mathrm{McH}$. and $\mathrm{R}$. H. received $100 \mathrm{mg}$. of cortisone a day there was a marked fall in 17-ketosteroid excretion. Under these circumstances, more loss of $\mathrm{N}$ was produced than has been observed following this dosage ${ }^{8}$ of cortisone. Thus in the first instance, with a rise of adrenal androgen unopposed by adrenal "sugar" hormone there was $\mathrm{N}$ retention, whereas in the second instance, with a fall of adrenal androgen there was an abnormally great $\mathrm{N}$ loss following exogenous "sugar" hormone.

\footnotetext{
$7 \mathrm{~N}$ retention did not occur in $\mathrm{R}$. $\mathrm{H}$. in spite of a greater rise in 17-ketosteroid excretion. This may be a result of qualitative differences in the precursors of the 17ketosteroids in these two patients $(13,24)$.

8 Either on an absolute or a $\mathrm{mg}$. per $\mathrm{kg}$. basis.
} 


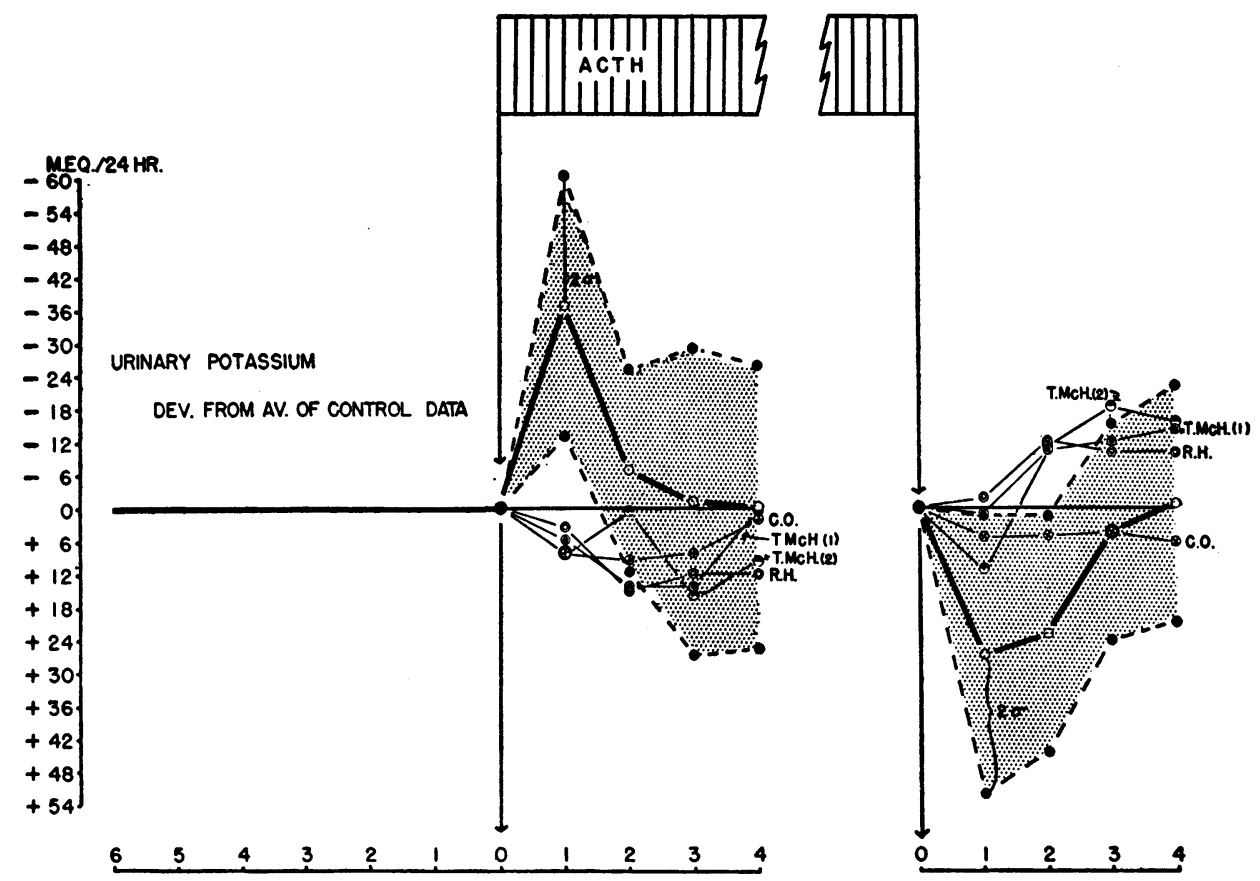

Fig. 11. The Urinary $\mathrm{K}$ Excretion during the First Four Days of, and the First Four Days after, Administration of ACTH to the Patients Reported Contrasted with that in 11 Comparable Experiments on Patients with Essentially Normal Adrenal Cortical FunCTION

The shaded area is that covered by two standard deviations above and below the mean normal curve (heavy black line). Note that patients with the adrenogenital syndrome did not show the $\mathrm{K}$ diuresis on starting nor the $\mathrm{K}$ retention on stopping ACTH.

\section{b) Clinical implications}

During these short metabolic studies, no clinically apparent change in these patients was expected or found. Subsequent to these studies, T. $\mathrm{McH}$. has received continuously $100 \mathrm{mg}$. of cortisone twice a week (total duration, five months to date of writing) and R. H. $50 \mathrm{mg}$. twice a week (total duration, six months to date of writing).

In neither patient has this therapy produced a fall in the number of circulating eosinophils; in both, it has maintained the 17 -ketosteroid excretion at a level approximately normal (19) for the patient's age and sex. T. McH. has begun to have regular periods with cramps. It is too early to say whether further virilism can be prevented by this form of therapy.

\section{c) Interpretation of the pathological physiology}

There are a number of possible explanations for the findings reported here. One such explanation is shown graphically in Figure 13. It is postulated that adrenal androgen inhibits pituitary ACTH production relatively weakly, whereas "sugar" hormones inhibit ACTH relatively strongly. It is suggested that the primary defect in this syndrome is the decreased production of "sugar" hormone by the adrenal cortex in response to ACTH. One then has the following sequence of events :

1) lack of "sugar" hormone,

2) failure of normal inhibition of ACTH,

3) increased output of $\mathrm{ACTH}$, and

4) resulting increase of adrenal androgen. 


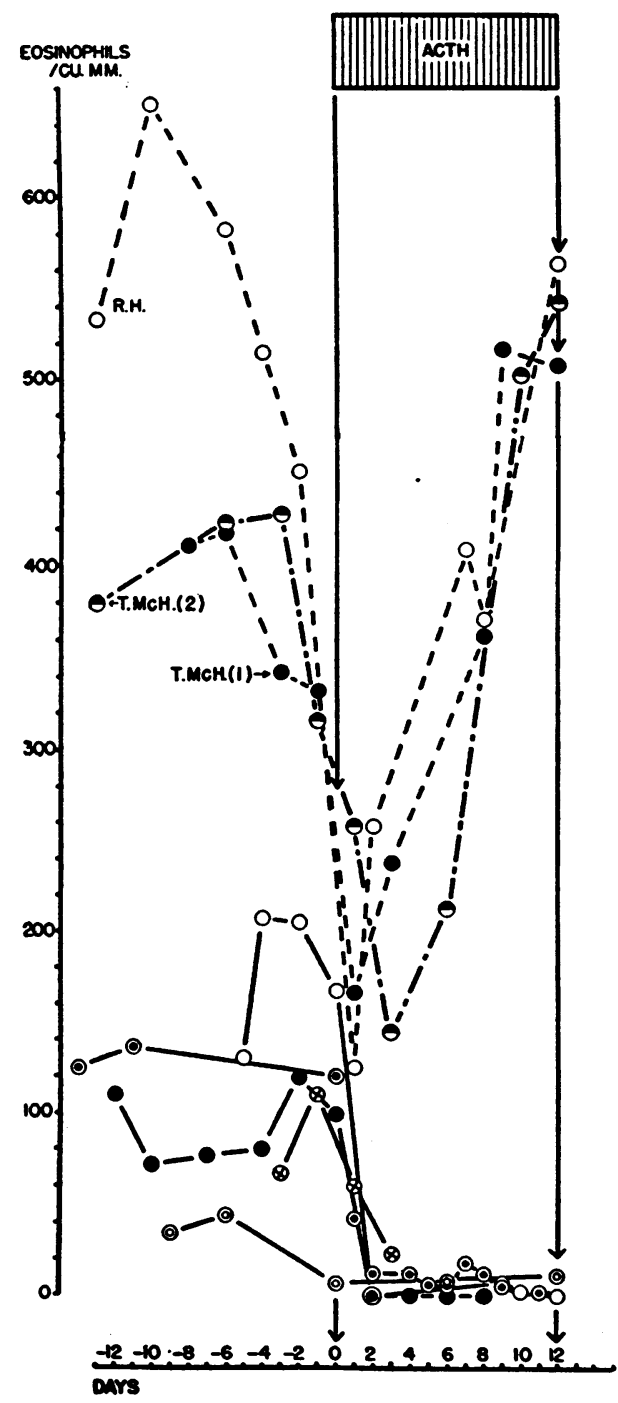

Fig. 12. The Effect of ACTH on the Circulating EOSINOPHILS IN Three OF THE EXPERIMENTS REPORTED (Broken Lines) Contrasted with that in Five Comparable Experiments on Patients with Essentially Normal Adrenal Cortical Function (Solid Lines)

Note the high initial level, and the comparatively slight and transitory fall in the patients with the adrenogenital syndrome.

This schema does not require that the patients show an absolute deficit of "sugar" hormone, since the increased production of ACTH may com- pletely compensate for the inherent insensitivity to ACTH.

That there is an increased production of ACTH in this syndrome has not been established. Dr. A. Albert (27) tested the serum of T. $\mathrm{McH}$. and could not demonstrate the presence of ACTH. He did, however, demonstrate the presence of increased amounts of ACTH in the serum of one adult patient from this clinic with a classical case of the adrenogenital syndrome.

\section{SUMMARY AND CONCLUSIONS}

1. Four courses of ACTH were administered to three female patients with the adrenogenital syndrome resulting from congenital adrenal hyperplasia. The dosage ranged from .71 to 3.33 mg. per day per $\mathrm{kg}$. body weight, the duration from nine to 12 days. Studies included urinary 17-ketosteroids, reducing steroids, glucose, and chloride, balances of $\mathrm{N}, \mathrm{P}, \mathrm{Ca}, \mathrm{K}, \mathrm{Mg}$, and $\mathrm{Na}$, and measurements of circulating eosinophils, serum $\mathrm{P}, \mathrm{Ca}, \mathrm{K}, \mathrm{Mg}, \mathrm{Cl}, \mathrm{CO}_{2}$ and glucose.

2. ACTH produced a rise in urinary 17 -ketosteroids in three of the four courses, but none of its other usual metabolic effects. With the highest dosage of ACTH there was actual nitrogen retention.

3. Cortisone acetate was administered to two of these patients on the same regimen. The dosages were 1.90 and $2.22 \mathrm{mg}$. per day per $\mathrm{kg}$. body weight, the duration 12 days.

4. Cortisone produced a fall to normal and even below normal in the elevated urinary 17-ketosteroid exçretion, and a negative $\mathrm{N}$ balance. The latter is exceptional at the dosages employed.

5. ACTH (2.05 mg. per kg. per day) and cortisone (2.32 mg. per $\mathrm{kg}$. per day) were administered together to one of these patients for eight days. The resulting rise in urinary 17-ketosteroids was essentially the same as that produced by $\mathrm{ACTH}$ alone.

6. Cortisone acetate is being administered continuously to two of these patients at dosages of 100 and $200 \mathrm{mg}$. a week. At this dosage the urinary 17 -ketosteroids remain normal and the circulating 


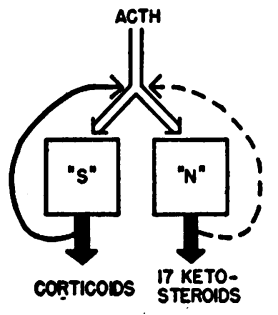

NORMAL

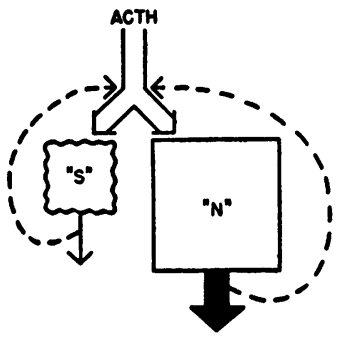

ADRENO - GENITAL

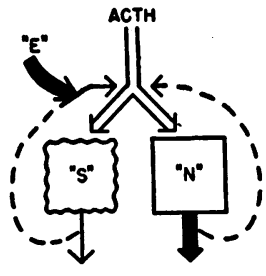

ADRENO-GENTAL

Fig. 13. Schema Illustrating a Possible Explanation for the Pathological Physiology of the Adrenogenital Syndrome and the EFFEct THEREON OF CoMpound $E$

The square figures represent the adrenal cortex. "S" refers to carbohydrate-active ("sugar") hormones, precursors of urinary corticoids; " $N$ " refers to "adrenal androgens," precursors of urinary 17-ketosteroids.

It is postulated that " $\mathrm{S}$ " hormones inhibit ACTH effectively (solid arrows directed backwards toward ACTH), whereas " $N$ " hormones do not (broken arrows directed backwards toward ACTH). For further discussion see text.

eosinophils are not depressed. One patient is having monthly periods with cramps.

7. The above findings suggest that this syndrome involves a primary defect of the adrenal cortex, and a secondary increase of pituitary $\mathrm{ACTH}$ production.

8. In all patients the electroencephalograms showed asymmetry, elevation of voltages, and abnormal slow waves. This finding is unexplained.

\section{REFERENCES}

1. Blackman, S. S., Jr., Concerning the function and origin of the reticular zone of the adrenal cortex; hyperplasia in the adrenogenital syndrome. Bull. Johns Hopkins Hosp., 1946, 78, 180.

2. Albright, F., Cushing's syndrome. Harvey Lectures, 1942-3, 38, 123.

3. Forsham, P. H., Thorn, G. W., Prunty, F. T. G., and Hills, A. G., Clinical studies with pituitary adrenocorticotropin. J. Clin. Endocrinol., 1948, 8, 15.

4. Conn, J. W., Louis, L. H., and Johnston, M. W., Metabolism of uric acid, glutathione, and nitrogen, and excretion of 11-oxysteroids and 17-ketosteroids during induction of diabetes in man with adrenocorticotropic hormone. J. Lab. \& Clin. Med., 1949, 34, 255.

5. Conn, J. W., Louis, L. H., and Wheeler, C. E., Production of temporary diabetes mellitus in man with pituitary adrenocorticotropic hormone; relation to uric acid metabolism. J. Lab. \& Clin. Med., 1948, 33, 651.

6. Sprague, R. G., Power, M. H., Mason, H. L., Albert, A., Mathieson, D. R., Hench, P. H., Kendall, E. C., Slocumb, C. H., and Polley, H. F., Obser- vations on the physiologic effects of cortisone and ACTH in man. Arch. Int. Med., 1950, 85, 199.

7. Bartter, F. C., Fourman, P., Albright, F., Forbes, A. P., Jefferies, W. McK., Griswold, G., Dempsey, E., Bryant, D., and Carroll, E., The effect of adrenocorticotropic hormone in panhypopituitarism. J. Clin. Invest., 1950, 29, 950.

8. Briggs, A. P., Some applications for the colorimetric phosphate method. J. Biol. Chem., 1924, 59, 255.

9. Talbot, N. B., Saltzman, A. H., Wixom, R. L., and Wolfe, J. K., The colorimetric assay of urinary corticosteroid-like substances. J. Biol. Chem., 1945, $160,535$.

10. Heard, R. D. H., Sobel, H., and Venning, E. H., The neutral lipide-soluble reducing substances of urine as an index of adrenal cortical function. J. Biol. Chem., 1946, 165, 699.

11. Hills, A. G., Forsham, P. H., and Finch, C. A., Changes in circulating leukocytes induced by the administration of pituitary adrenocorticotropic hormone in man. Blood, 1948, 3, 755.

12. Reifenstein, E. C., Jr., Albright, F., and Wells, S. L., The accumulation, interpretation, and presentation of data pertaining to metabolic balances, notably those of calcium, phosphorus, and nitrogen. J. Clin. Endocrinol., 1945, 5, 367.

13. Talbot, N. B., Zygmuntowicz, A. N., Wood, M., and Christo, E., Observations on adrenal cortical "sugar-fat-nitrogen" hormone ("11-17-OCS") and "17-ketosteroid precursor" production by normal and abnormal individuals of various ages with comments on the fact that (a) there may be two ACTH's and (b) the normal adrenal cortex may not produce true androgens, in Proceedings of the First Clinical ACTH Conference, John R. Mote, Editor. Blakiston Co., Philadelphia, 1950, p. 32. 
14. Bartter, F. C., Fourman, P., Albright, F., Jefferies, W. McK., Dempsey, E., and Carroll, E., Does methyl testosterone modify the effects of adrenocorticotropic hormone (ACTH) and of desoxycorticosterone glucoside (DOCG) ? Symposium on Adrenal Cortex, American Association for the Advancement of Science, Washington, 1950.

15. Bartter, F. C., Forbes, A. P., and Albright, F., A comparison of the effects of ACTH in panhypopituitarism, ovarian agenesis and acromegaly, in Proceedings of the First Clinical ACTH Conference, John R. Mote, Editor. Blakiston Co., Philadelphia, 1950, p. 214.

16. Bartter, F., and Albright, F., The effects of anterior pituitary adrenocorticotropic hormone (ACTH) on bone metabolism, in Tr. of Second Conf. on Metabolic Interrelations. Josiah Macy, Jr. Foundation, January, 1950, p. 258.

17. Ingbar, S. H., Relman, A. S., Barrows, B. A., Kass, E. H., Sisson, J. H., and Burnett, C. H., Changes in normal renal function resulting from ACTH and cortisone. J. Clin. Invest., 1950, 29, 824.

18. Lewis, R. A., and Wilkins, L., The effect of adrenocorticotrophic hormone in congenital adrenal hyperplasia with virilism and in Cushing's syndrome treated with methyl testosterone. J. Clin. Invest., 1949, 28, 394.

19. Talbot, N. B., Butler, A. M., Berman, R. A., Rodriguez, P. M., and MacLachlan, E. A., Excretion of 17-ketosteroids by normal and by abnormal children. Am. J. Dis. Child., 1943, 65, 364.
20. Fourman, P., Bartter, F. C., Albright, F., Dempsey, E., Carroll, E., and Alexander, J., Effects of 17hydroxy-corticosterone ("compound F") in man. J. Clin. Invest., 1950, 29, 1462.

21. Clark, W. S., Ropes, M. W., and Bauer, W., Changes produced by the administration of ACTH and cortisone in rheumatoid arthritis, in Proceedings of the First Clinical ACTH Conference, John R. Mote, Editor. Blakiston Co., Philadelphia, 1950, p. 337.

22. Unpublished data.

23. Wilkins, L., Lewis, R. A., Klein, R., and Rosemberg, E., The suppression of androgen secretion by cortisone in a case of congenital adrenal hyperplasia: preliminary report. Bull. Johns Hopkins Hosp., 1950, 86, 249.

24. Engstrom, W. W., Nature and significance of neutral steroids in human urine in normal and abnormal states, with preliminary consideration of adrenal and gonadal steroids and factors which influence their secretion and biological action. Yale J. Biol. \& Med., 1948, 21, 21.

25. Forbes, A. P., Griswold, G. C., and Albright, F., Clinical experience with a bioassay method for the determination of urinary corticosteroids. J. Clin. Endocrinol., 1950, 10, 230.

26. Talbot, N. B., Albright, F., Saltzman, A. H., Zygmuntowicz, A., and Wixom, R., The excretion of 11-oxycorticosteroid-like substances by normal and abnormal subjects. J. Clin. Endocrinol., 1947, 7, 331.

27. Albert, A., Personal communication.

\section{ERRATUM}

In Table VII of the article entitled "Acetylation Studies in $\mathrm{Hu}$ man Subjects with Metabolic Disorders," by H. Gershberg and W. J. Kuhl, Jr., in the December 1950 issue (pp. 1625-1632), the values for both total and free serum cholesterol are $m g m$. per cent rather than as erroneously given. 